\title{
Assessment of Organochlorine Pesticide Residues in the Surface Sediments of River Yamuna in Delhi, India
}

\author{
Puneeta Pandey*, P. S. Khillare, Krishan Kumar \\ School of Environmental Sciences, Jawaharlal Nehru University, New Delhi, India. \\ Email: puneetapandey@gmail.com \\ Received February $4^{\text {th }}, 2011$; revised April 22 $2^{\text {nd }}, 2011$; accepted June $3^{\text {rd }}, 2011$.
}

\begin{abstract}
The present study reports the concentration levels and distribution patterns of the organochlorine pesticide residues in the surface sediments of river Yamuna in the Indian capital state, Delhi. Analytical measurements were carried out for twenty organochlorine pesticides (OCPs) in the Pre-monsoon, Monsoon and Post-monsoon seasons, at six different sampling locations along the $22 \mathrm{~km}$ stretch of the river Yamuna in Delhi. The results revealed contamination of the surface sediments with several persistent organochlorine pesticides. Endrin aldehyde, Endosulfan sulfate and DDT showed the highest percentage composition of OCP at all the sampling sites in all the three seasons. The total organochlorine pesticides level ranged from 157.71 - $307.66 \mathrm{ng} / \mathrm{g}$ in Pre-monsoon to 195.86 - $577.74 \mathrm{ng} / \mathrm{g}$ in Monsoon and $306.9-844.45 \mathrm{ng} / \mathrm{g}$ in the Post-monsoon season. This not only demonstrates the pollution of the river with pesticide residues, but also the necessity of a continuous long-term monitoring of the affected environment.
\end{abstract}

Keywords: Persistent Organic Pollutants (POPs), Organochlorine Pesticides (OCPs), Yamuna River, Sediments

\section{Introduction and Methods}

Persistent organic pollutants (POPs) are a major group of hazardous chemicals having anthropogenic origin and three main characteristics: persistence, bioaccumulation and long range transport [1]. In the recent years, there has been a growing interest in these chemicals due to their potential toxicity and adverse impacts on human health [2]. The Stockholm Convention on POPs (2001) is an outcome of this growing concern about the persistent organic pollutants. As per the Stockholm Convention, POPs include nine organochlorine pesticides (OCPs) and three industrial chemicals or by-products. The nine pesticides targeted by the Stockholm Convention were produced internationally and used on agricultural crops or for public health vector control. By 1970s, these pesticides were either banned or restricted in many countries. Though banned, these chemicals are still being used in some of the developing countries owing to their low cost and versatility in industry, agriculture and public health [3]. In the Indian context, there are currently 179 pesticides registered for use in India; 30 others have been banned, while seven are restricted, including DDT. Aldrin, chlordane and heptachlor were banned in Sep- tember, 1996; while DDT is in restricted use since July, 1989. Dieldrin came in restricted use since May, 1990 and was banned completely in July, 2003. Endrin was banned in May, 1990 while HCH in April, 1997. Use of endosulfan and methoxychlor has been permitted while HCB was never registered as a pesticide [4].

One of the important sink and reservoir for persistent pollutants discharged into the environment is the sediment found on river and lake beds [5]. Sediment is a matrix of materials which is comprised of detritus, inorganic and organic particles, and is relatively heterogeneous in terms of its physical, chemical and biological characteristics [6]. Though regarded as a sink, the sediments may release back to overlying waters the metals and other pollutants bound on it, as a result of remobilization due to various diagenetic processes [7]. As a result, sediments are now regarded as an important source of many micropollutants that seriously threaten natural ecosystems [8].

River Yamuna, a tributary of River Ganga is a major river in the North Indian Plains. Along its entire $1376 \mathrm{~km}$ stretch from Yamunotri to Allahabad, its water quality is influenced by three major urban centers, i.e. Delhi, 
Mathura-Vrindavan and Agra. Among these three, Delhi's contribution of pollution load into the river Yamuna is the greatest. It also receives a fair amount of pesticides as runoff from the agricultural fields of Haryana upstream to its entry point in Delhi. A variety of vegetables are grown in Yamuna flood plains in Delhi, where use of OCPs is quite prominent. Besides, inundation of surface sediments along the banks of Yamuna cannot be ruled out in the monsoon season.

Owing to the greater environmental significance of OCPs in Indian context and highly polluted status of the river Yamuna, the study envisages having a proper assessment of the residual presence of OCPs in Yamuna river sediment. Thus, the objective of the present study was:

1) To determine the concentration levels of organochlorine pesticides in surface sediment of the river Yamuna in Delhi

2) To obtain trends in spatial and temporal variation of organochlorine pesticides concentration.

The results obtained may be made use of as a baseline data in developing effective remedial measures to improve the water quality status of the river.

\section{Materials and Method}

\subsection{Site Description}

Delhi, the capital state of India, is situated at latitude of $28^{\circ} 24^{\prime} 17^{\prime \prime}$ to $28^{\circ} 53^{\prime}$ and the longitude of $76^{\circ} 20^{\prime} 37^{\prime \prime}$ to $77^{\circ} 20^{\prime} 37^{\prime \prime}$, with an altitude of 216 meters above mean sea level. For the collection of sediment samples from the river Yamuna, six sampling sites were selected along the river Yamuna in Delhi. Site A (RG), was taken upstream to the city, three sites $\mathrm{B}, \mathrm{C}$ and $\mathrm{D}$ in the middle segment (NGUS, NGDS and ITO) respectively and two sites $\mathrm{E}(\mathrm{OK})$ and $\mathrm{F}(\mathrm{KK})$ downstream to the city. Figure 1 represents map of the River Yamuna in Delhi showing the six sampling sites. Sediment samples were collected from these sites for Pre-monsoon (June), Monsoon (August) and Post-monsoon (October) season and analyzed for 20 organochlorine pesticides.

\subsection{Reagents}

Standard mixture containing twenty-two OCPs $(22$ compounds specified in EPA method 8081B) was purchased from Supelco (Sigma Aldrich, USA). All solvents (acetone, hexane, dichloromethane etc.) used for sample processing and analysis, were of HPLC grade.

\subsection{Sample Preparation}

At each sampling site, the samples were collected in triplicates with the help of a stainless steel auger, transferred into polythene bags and transported to laboratory. After

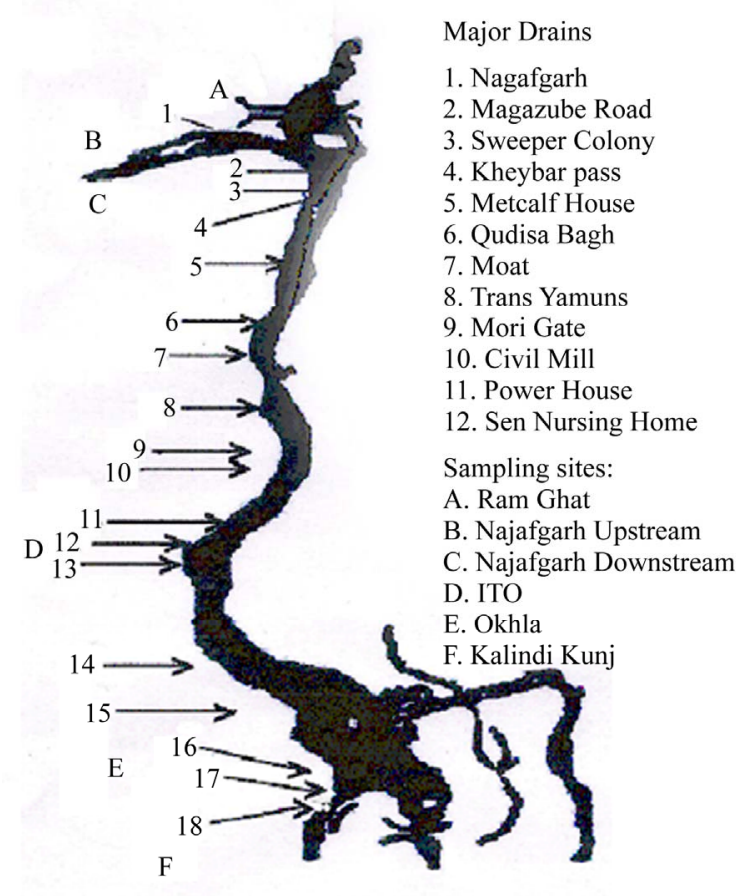

Figure 1. Map of the Yamuna River in Delhi showing sampling sites.

drying, the samples were mixed thoroughly by the quartering method and then sieved through a $2 \mathrm{~mm}$ sieve. The sediment samples were extracted by Soxhlet extraction method (USEPA Method 3540 [26,39,34]. Then, the cleanup was carried out by Silica Gel (Silica gel 60, particle size $0.0630-0.200 \mathrm{~mm}, 70$ - 230 mesh ASTM purchased from Merck KgaA, Darmstadt, Germany) Cleanup Method (USEPA Method 3630C).

\subsection{Analysis}

All the samples were analyzed on Gas Chromatograph (Perkin Elmer Instruments, AutoSystem XL GC), equipped with ECD (Electron Capture Detector) and a PerkinElmer wide-bore capillary column (PE-5 column) with the dimensions $30 \mathrm{~m} \times 0.53 \mathrm{~mm}$ i.d. $\times 1.5 \mu \mathrm{m}$.

\section{Results and Discussion}

In the present study, Endosulfan I and $\alpha$-Chlordane have been reported together, since they appeared as joint peak and could not be resolved. For similar reasons, Endosulfan sulfate + DDT have also been reported together.

\subsection{Spatial Variation of Organochlorine Pesticides Concentration}

In the pre-monsoon period, the total OCPs $(\Sigma$ OCP) concentration ranged from $157.71 \mathrm{ng} / \mathrm{g}$ at Ramghat to 307.66 $\mathrm{ng} / \mathrm{g}$ at Najafgarh Upstream (NGUS). The high concen- 
tration of pesticides at RG and NGUS can be attributed to the pollution load added from the neighboring state of Haryana as well as the increased sewage flow in the river. Since the flow decreases downstream, the concentration of $\Sigma$ OCP decreased which could be due to degradation of OCPs in summer due to high temperature. A very low value at NGDS could be due to microbial action which further accelerated the degradation processes.

In the monsoon period, the highest average seasonal concentration was found at KK $(577.74 \mathrm{ng} / \mathrm{g})$, while minimum concentration was at NGUS (195.86 ng/g). During monsoon season, the major source of organic pollution is industrial wastewater, runoff from agricultural fields in Haryana upstream of Delhi and Yamuna floodplains, garbage dumps and city streets carrying litter. Since the distribution during monsoon is very heterogenous, it can be said that since the flow of river increased during monsoon, the pollution load was carried downstream to Kalindi Kunj. Further each site also received runoff from local sources, especially the Najafgarh drain, hence a high value was observed at NGDS (due to Najafgarh drain), and Okhla (due to Yamuna flood plains).

In the post-monsoon period, the total OCPs ( $\Sigma$ OCP) concentration ranged from $306.9 \mathrm{ng} / \mathrm{g}$ at NGDS to $844.45 \mathrm{ng} / \mathrm{g}$ at RG. During Post-monsoon season, besides contribution from runoff from fields in Haryana, some of the pesticides find their way into the sediments due to leaching [9], as there seems to be a time lag between peak water flow and OCPs reaching the sediment matrix of the river. Further, the degradation may not have been substantial as there was a time difference of two months only between monsoon and post-monsoon sampling, hence such a high value was observed at Ramghat. Similarly, a high value at ITO could be due to runoff from agricultural fields in its vicinity, which had not degraded much. The value is low at NGDS, however, the difference between NGUS and NGDS is not much pronounced in post-monsoon, as in pre- monsoon. The concentration of individual OCPs in the pre-monsoon, monsoon and post-monsoon season has been given in Table 1, 2 and $\mathbf{3}$ respectively.

Considering the distribution of OCPs at various sampling sites, Endrin aldehyde revealed the highest concentration at all the sites except NGDS, wherein Endosulfan sulfate + DDT dominated during pre-monsoon season. In the monsoon season, Endosulfan sulfate + DDT revealed the highest concentration at RG, NGUS, ITO and OK, while heptachlor epoxide revealed the highest concentration at NGDS and KK. Finally, during post-monsoon season, Endosulfan sulfate + DDT showed the highest concentration at NGUS, NGDS, ITO and OK, Endrin aldehyde at RG, and heptachlor epoxide at KK. Thus,

Table 1. Spatial variation of OCPs in sediment at different sites of River Yamuna (Pre-monsoon period).

\begin{tabular}{|c|c|c|c|c|c|c|}
\hline OCPs & RG & NGUS & NGDS & ITO & $\mathbf{O K}$ & KK \\
\hline$\alpha-\mathrm{BHC}$ & $12.33 \pm 1.52$ & $3.95 \pm 0.81$ & $12.42 \pm 1.06$ & $7.25 \pm 0.79$ & $6.51 \pm 0.62$ & $6.1 \pm 0.67$ \\
\hline$\beta$-BHC & $7.55 \pm 0.86$ & $4.5 \pm 0.56$ & $1.07 \pm 0.34$ & $1.19 \pm 0.26$ & $1.2 \pm 0.11$ & $0.31 \pm 0.05$ \\
\hline$\gamma-\mathrm{BHC}$ & $9.64 \pm 0.73$ & $0.38 \pm 0.23$ & $7.85 \pm 0.96$ & $3.74 \pm 0.45$ & $0.37 \pm 0.09$ & $0.88 \pm 0.12$ \\
\hline$\delta$-BHC & $6.99 \pm 0.54$ & $1.65 \pm 0.54$ & $7.13 \pm 0.85$ & $0.11 \pm 0.09$ & $3.22 \pm 0.31$ & $0.81 \pm 0.14$ \\
\hline Hep & $6.94 \pm 0.41$ & $7.36 \pm 0.81$ & $4.7 \pm 0.26$ & $1.5 \pm 0.18$ & $0.79 \pm 0.21$ & $0.83 \pm 0.08$ \\
\hline Ald & $3.42 \pm 0.28$ & $14.51 \pm 0.64$ & $5.81 \pm 0.25$ & $7.51 \pm 0.46$ & $6.64 \pm 0.54$ & $5.29 \pm 0.56$ \\
\hline Hepex & $2.55 \pm 0.56$ & $13.76 \pm 0.95$ & $2.09 \pm 0.32$ & $8.53 \pm 1.04$ & $8.04 \pm 0.87$ & $8.6 \pm 0.96$ \\
\hline$\gamma-\mathrm{Chl}$ & $2.28 \pm 0.14$ & $15.44 \pm 0.58$ & $2.63 \pm 0.12$ & $9.22 \pm 1.5$ & $5.58 \pm 0.81$ & $3.76 \pm 0.41$ \\
\hline Ends $1+\alpha-C h l$ & $0.11 \pm 0.23$ & $8.78 \pm 0.74$ & $0.37 \pm 0.11$ & $5.08 \pm 0.41$ & $4.12 \pm 0.52$ & $3.08 \pm 0.59$ \\
\hline DDE & $4.88 \pm 0.61$ & $24.58 \pm 0.56$ & $8.51 \pm 1.05$ & $18.43 \pm 0.99$ & $14.17 \pm 1.11$ & $9.97 \pm 1.01$ \\
\hline Dield & $5.49 \pm 0.39$ & $25.18 \pm 2.11$ & $9.91 \pm 1.54$ & $18.08 \pm 1.14$ & $13.58 \pm 1.55$ & $11.36 \pm 1.52$ \\
\hline End & $13.7 \pm 1.24$ & $31.48 \pm 1.96$ & $16.02 \pm 2.15$ & $22.55 \pm 2.13$ & $18.78 \pm 1.46$ & $17.01 \pm 1.15$ \\
\hline Ends2 & $11.34 \pm 1.92$ & $24.44 \pm 3.14$ & $16.14 \pm 1.52$ & $16.62 \pm 1.84$ & $14.96 \pm 2.14$ & $16.76 \pm 2.15$ \\
\hline DDD & $13.42 \pm 2.14$ & $24.42 \pm 1.85$ & $17.11 \pm 1.68$ & $17.27 \pm 1.31$ & $14.84 \pm 1.84$ & $20.08 \pm 1.64$ \\
\hline Endal & $21.89 \pm 0.98$ & $33.19 \pm 1.27$ & $27.28 \pm 1.86$ & $25.21 \pm 1.55$ & $23.47 \pm 2.11$ & $29.67 \pm 2.18$ \\
\hline Endosu + DDT & $21.56 \pm 1.45$ & $26.67 \pm 1.52$ & $28.56 \pm 1.45$ & $24.16 \pm 2.13$ & $20.59 \pm 1.26$ & $29.14 \pm 1.67$ \\
\hline Endket & $5.9 \pm 0.53$ & $20.72 \pm 1.19$ & $11.19 \pm 1.04$ & $18.83 \pm 1.41$ & $15.91 \pm 1.06$ & $11.45 \pm 1.06$ \\
\hline Meth & $7.72 \pm 0.61$ & $26.65 \pm 2.56$ & $11.44 \pm 0.45$ & $23.2 \pm 1.58$ & $19.34 \pm 1.18$ & $11.56 \pm 0.98$ \\
\hline TOTAL & 157.71 & 307.66 & 190.23 & 228.48 & 192.11 & 186.66 \\
\hline
\end{tabular}


Table 2. Spatial variation of OCPs in sediment at different sites of River Yamuna (Monsoon period).

\begin{tabular}{|c|c|c|c|c|c|c|}
\hline OCPs & RG & NGUS & NGDS & ITO & OK & $\mathrm{KK}$ \\
\hline$\alpha-\mathrm{BHC}$ & $6.87 \pm 1.31$ & $15.34 \pm 1.21$ & $14.26 \pm 1.21$ & $6.67 \pm 0.98$ & $25.49 \pm 1.61$ & $18.99 \pm 0.82$ \\
\hline$\beta-\mathrm{BHC}$ & $1.6 \pm 0.23$ & $12.64 \pm 1.32$ & $19.68 \pm 1.62$ & $3.99 \pm 0.64$ & $30.27 \pm 1.87$ & $23.31 \pm 0.93$ \\
\hline$\gamma$-BHC & $5.91 \pm 1.1$ & $12.26 \pm 1.12$ & $17.05 \pm 1.54$ & $4.07 \pm 0.71$ & $27.85 \pm 1.56$ & $26.28 \pm 1.1$ \\
\hline$\delta$-BHC & $1.04 \pm 0.24$ & $8.95 \pm 0.95$ & $14.95 \pm 1.35$ & $0.39 \pm 0.23$ & $20.99 \pm 0.89$ & $15.48 \pm 0.79$ \\
\hline Hep & $3.33 \pm 0.67$ & $9.88 \pm 0.89$ & $14.09 \pm 1.26$ & $3.16 \pm 0.45$ & $25.23 \pm 0.98$ & $15.82 \pm 0.81$ \\
\hline Ald & $1.05 \pm 0.21$ & $6.87 \pm 0.87$ & $18.39 \pm 1.98$ & $3.79 \pm 0.56$ & $29.1 \pm 1.69$ & $20.98 \pm 1.23$ \\
\hline Hepex & $6.76 \pm 0.98$ & $4.15 \pm 0.79$ & $78.18 \pm 2.14$ & $26.17 \pm 1.76$ & $35.56 \pm 1.98$ & $72.5 \pm 2.63$ \\
\hline$\gamma-\mathrm{Chl}$ & $6.34 \pm 1.1$ & $2.96 \pm 0.54$ & $10.95 \pm 1.24$ & $1.32 \pm 0.43$ & $23.71 \pm 0.95$ & $17.73 \pm 0.74$ \\
\hline Ends $1+\alpha-C h l$ & $1.49 \pm 1.23$ & $1.1 \pm 0.36$ & $8.58 \pm 0.97$ & $2.44 \pm 0.67$ & $15.63 \pm 0.78$ & $12.42 \pm 0.68$ \\
\hline DDE & $10.17 \pm 2.31$ & $3.45 \pm 0.62$ & $21.61 \pm 1.99$ & $10.69 \pm 1.26$ & $29.45 \pm 1.72$ & $26.24 \pm 1.21$ \\
\hline End & $17.43 \pm 1.73$ & $12.14 \pm 1.26$ & $30.31 \pm 2.24$ & $20.34 \pm 1.67$ & $33.78 \pm 1.82$ & $32.72 \pm 1.64$ \\
\hline Ends2 & $17.81 \pm 1.62$ & $13.08 \pm 1.32$ & $31.44 \pm 2.35$ & $21.31 \pm 1.78$ & $33.71 \pm 1.79$ & $33.13 \pm 1.76$ \\
\hline DDD & $21.57 \pm 2.86$ & $16.01 \pm 1.52$ & $47.12 \pm 2.56$ & $26.89 \pm 1.98$ & $42.64 \pm 1.94$ & $47.34 \pm 1.86$ \\
\hline Endal & $29.54 \pm 2.94$ & $23.52 \pm 1.73$ & $44.33 \pm 2.48$ & $34.17 \pm 2.13$ & $43.16 \pm 2.1$ & $49.68 \pm 1.92$ \\
\hline Endosu + DDT & $34.14 \pm 3.14$ & $26.67 \pm 1.99$ & $78.23 \pm 2.87$ & $40.84 \pm 2.36$ & $55.01 \pm 2.76$ & $71.49 \pm 2.43$ \\
\hline Endket & $17.44 \pm 1.64$ & $10.25 \pm 0.98$ & $21.89 \pm 2.11$ & $21.15 \pm 1.59$ & $21.76 \pm 0.94$ & $32.12 \pm 1.56$ \\
\hline Meth & $18.69 \pm 1.82$ & $10.76 \pm 1.1$ & $22.01 \pm 2.23$ & $22.93 \pm 1.76$ & $22.55 \pm 0.98$ & $33.9 \pm 1.68$ \\
\hline TOTAL & 213.99 & 195.86 & 551.49 & 263.11 & 546.6 & 577.74 \\
\hline
\end{tabular}

Table 3. Spatial variation of OCPs in sediment at different sites of River Yamuna (Post-monsoon period).

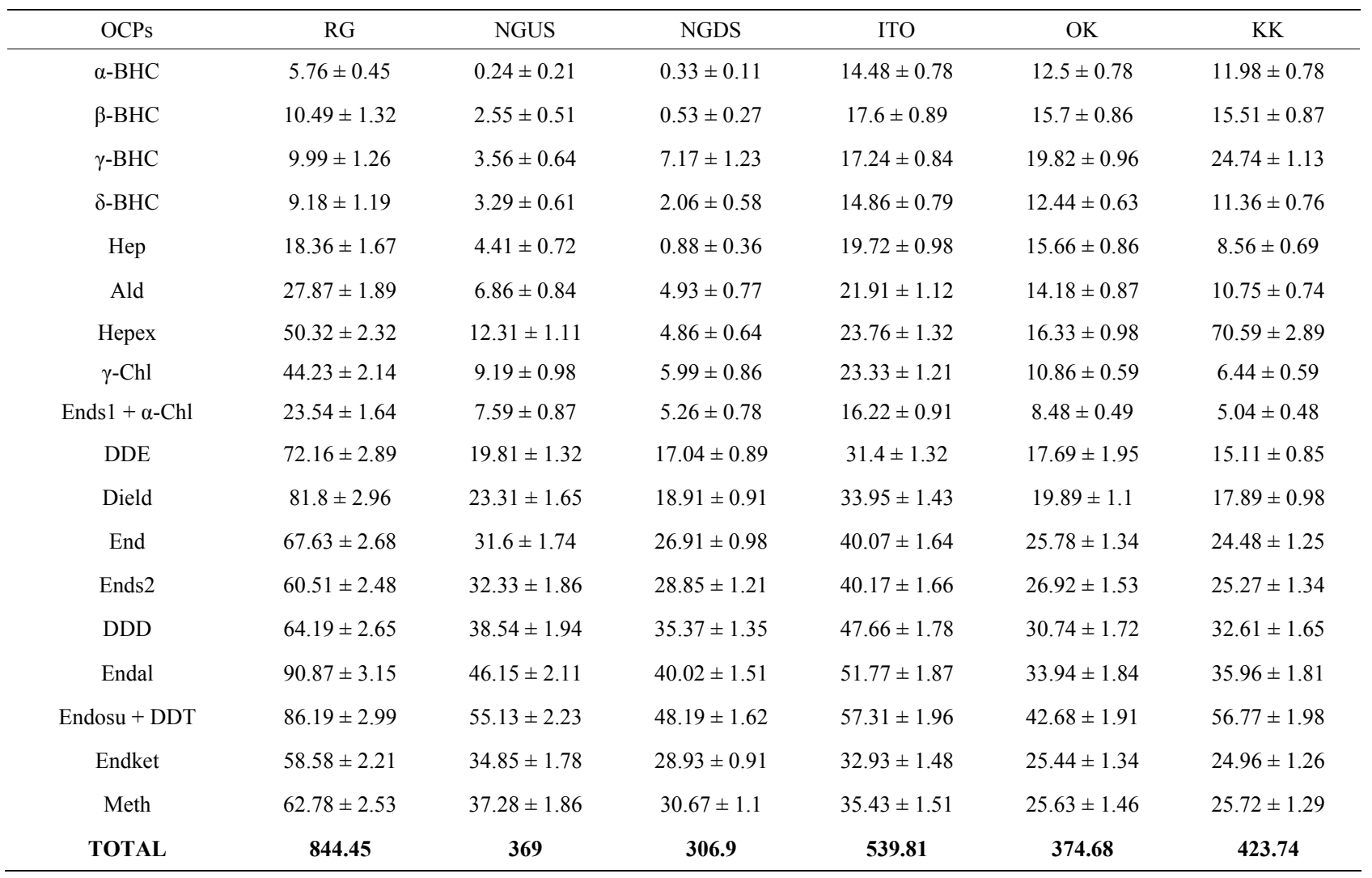


Endosufan sulfate + DDT, Endrin aldehyde, DDD, Endrin and Methoxychlor were found in significant concentrations at all the sites in all the seasons, indicating their wide use. Dominance of DDT in the sediments may be attributed to the slow degradation of DDTs or recent input of DDT in the environment $[10,11]$. Since Delhi is highly urbanized, this possibility cannot be ruled out, though use of DDT in agricultural applications has been completely banned but vector control programmes are effectively being carried out in this part of the country. India is ranked the biggest consumer and manufacturer of $\mathrm{HCH}$ and DDT in the world [12]. Moreover, pre-dominance of Endrin aldehyde suggests the decomposition of Endrin to Endrin aldehyde. The results of the present study are consistent with the findings of Cavanagh et. al. (1999) [13] that the volatilization of POPs such as OCPs occurs in warmer climate of tropical regions. Methoxychlor is tightly bound to soil and is insoluble in water, so it is not expected to be very mobile in moist soils $[14,15]$. Methoxychlor breaks down slowly in air, water and soil by sunlight and microscopic organisms. It may take several months [16], thus, explaining its abundance in sediments.

\subsection{Correlation}

Correlation analysis was performed by using univariate Pearson correlation coefficient for all pairs of compounds to determine relationships between individual compounds. Due to their extensive previous applications in agriculture and resistance to degradation, all organochlorine pesticides were found in significant concentrations at all the sampling sites. All the organochlorine pesticides may have a common source of origin and similar environmental behaviour, they may, therefore, display significant positive correlations among themselves [9]. Detailed analysis of the data set showed that there were some significant correlations existing between a few components in the sediments with correlation coefficients frequently greater than 0.5. $\alpha$ - BHC was found to be significantly correlated to the other BHC isomers due to similar chemical properties, thus, indicating association between them in terms of their applications. A very strong correlation was observed among Endosulfan1 $+\alpha$-Chlordane, DDE, Dieldrin, Endrin, Endosulfan2, DDD, Endrin aldehyde, Endosulfan sulfate + DDT, Endrin ketone and Methoxychlor $(0.72-0.99)$. This can be attributed to the fact that all OCPs are all related derivatives, and that they are commonly used in agriculture and vector control programmes. Further, since these compounds bind tightly to soil and sediments, this explains their presence even long time after discharge. The correlation values for the 20 pesticides in the surface sediments are shown in Table 4.

Table 4. Correlation coefficient matrix for individual OCPs.

\begin{tabular}{|c|c|c|c|c|c|c|c|c|c|c|c|c|c|c|c|c|c|c|}
\hline \multicolumn{5}{|c|}{$a l-B H C b-B H C g-B H C d-B H C$} & \multirow[t]{2}{*}{ Нер } & \multirow[t]{2}{*}{ Ald } & \multirow[t]{2}{*}{ Нерех } & \multirow[t]{2}{*}{$g-C h l$} & \multirow{2}{*}{$\begin{array}{c}\text { Ends1 } \\
+ \\
\text { al-Chl }\end{array}$} & \multirow[t]{2}{*}{$D D E$} & \multirow[t]{2}{*}{ Dield } & \multirow[t]{2}{*}{ End } & \multirow[t]{2}{*}{ Ends2 } & \multirow[t]{2}{*}{$D D D$} & \multirow{2}{*}{ Endal } & \multirow{2}{*}{$\begin{array}{l}\text { Endosu } \\
+D D T\end{array}$} & \multirow{2}{*}{ Endket } & \multirow[t]{2}{*}{ Meth } \\
\hline al-BHC & 1 & & & & & & & & & & & & & & & & & \\
\hline b-BHC & 0.85 & 1 & & & & & & & & & & & & & & & & \\
\hline g-BHC & 0.81 & 0.92 & 1 & & & & & & & & & & & & & & & \\
\hline d-BHC & 0.86 & 0.95 & 0.92 & 1 & & & & & & & & & & & & & & \\
\hline Hep & 0.73 & 0.91 & 0.79 & 0.91 & 1 & & & & & & & & & & & & & \\
\hline Ald & 0.54 & 0.79 & 0.63 & 0.78 & 0.91 & 1 & & & & & & & & & & & & \\
\hline Hepex & 0.39 & 0.64 & 0.6 & 0.59 & 0.5 & 0.57 & 1 & & & & & & & & & & & \\
\hline g-Chl & 0.18 & 0.47 & 0.33 & 0.47 & 0.72 & 0.87 & 0.36 & 1 & & & & & & & & & & \\
\hline $\begin{array}{l}\text { Ends1 }+ \\
\text { al-Chl }\end{array}$ & 0.23 & 0.56 & 0.42 & 0.55 & 0.77 & 0.92 & 0.44 & 0.97 & 1 & & & & & & & & & \\
\hline DDE & 0 & 0.32 & 0.21 & 0.33 & 0.58 & 0.79 & 0.38 & 0.97 & 0.93 & 1 & & & & & & & & \\
\hline Dield & -0.02 & 0.3 & 0.2 & 0.31 & 0.57 & 0.76 & 0.38 & 0.96 & 0.92 & 1 & 1 & & & & & & & \\
\hline End & -0.02 & 0.35 & 0.25 & 0.36 & 0.61 & 0.79 & 0.42 & 0.95 & 0.95 & 0.98 & 0.98 & 1 & & & & & & \\
\hline Ends2 & 0.05 & 0.44 & 0.36 & 0.45 & 0.66 & 0.8 & 0.49 & 0.91 & 0.94 & 0.93 & 0.94 & 0.97 & 1 & & & & & \\
\hline DDD & 0.18 & 0.58 & 0.51 & 0.57 & 0.7 & 0.81 & 0.65 & 0.82 & 0.89 & 0.83 & 0.84 & 0.89 & 0.96 & 1 & & & & \\
\hline Endal & -0.01 & 0.35 & 0.28 & 0.37 & 0.58 & 0.73 & 0.47 & 0.89 & 0.89 & 0.94 & 0.96 & 0.96 & 0.98 & 0.93 & 1 & & & \\
\hline $\begin{array}{l}\text { Endosu } \\
+ \text { DDT }\end{array}$ & 0.21 & 0.59 & 0.57 & 0.59 & 0.64 & 0.72 & 0.79 & 0.69 & 0.76 & 0.72 & 0.73 & 0.78 & 0.87 & 0.96 & 0.86 & 1 & & \\
\hline Endket & -0.17 & 0.24 & 0.22 & 0.24 & 0.45 & 0.62 & 0.38 & 0.82 & 0.84 & 0.89 & 0.91 & 0.93 & 0.95 & 0.88 & 0.94 & 0.8 & 1 & \\
\hline Meth & -0.22 & 0.19 & 0.15 & 0.18 & 0.41 & 0.61 & 0.34 & 0.83 & 0.84 & 0.9 & 0.91 & 0.94 & 0.93 & 0.84 & 0.92 & 0.75 & 0.99 & 1 \\
\hline
\end{tabular}




\subsection{Ratios of OCPs}

Isomeric ratios of Dieldrin/Aldrin, Heptachlor epoxide/ Heptachlor, DDD/DDE and $\alpha$-BHC $\gamma$-BHC have been given in Table 5.

\subsubsection{Dieldrin/Aldrin}

In the environment, aldrin gets converted to dieldrin, which is more stable. In the present study, the ratio observed was not much higher, suggesting high persistency of chemical in the environment. However, a very high value was observed at Ramghat in the monsoon season, which could be due to runoff from agricultural fields in Haryana, upstream of Ramghat. Although Aldrin was being used as an anti-termite agent against potato crops earlier, it is under complete ban in the country since September, 1996 [4].

\subsubsection{Heptachlor Epoxide/Heptachlor}

The ratio of heptachlor epoxide to heptachlor in the sediments ranged between $0.37-10.36$, thus, indicating the early time usage of the pesticide in the region. Heptachlor gets metabolized to heptachlor epoxide in the environment, which is more stable. Heptachlor epoxides adsorb strongly to the soil and are very resistant to biodegradation [17]. During pre- monsoon, the ratio was moderately high at ITO and considerably high at Okhla and Kalindi Kunj, which indicates greater degradation of heptachlor due to high temperature conditions. In monsoon, the ratio was high at Najafgarh downstream and Okhla, which may be due to fresh inputs from the drains. Further, in post- monsoon, ratio was high only at Kalindi Kunj, indicating transport of pollution load downstream.

\subsubsection{DDD/DDE}

The ratio of only DDD/DDE was taken and not (DDE + DDD)/DDT because DDT could not be separated from Endosulfan sulfate, hence could not be quantified. Both DDD and DDE are degradation products of DDT. DDT is degraded under aerobic conditions by micro-organisms to DDE and under anaerobic conditions to DDD. The ratio in this study varied from $0.22-1.12$, indicating more inputs of DDE and DDD to sediment from the wea- thered DDT, and there has not been much recent exposure to DDT in the environment [18]. Further, this reflects the aerobic conditions of the weathering process of DDTs in sediments in recent years [19].

\subsection{4. $\alpha-\mathrm{BHC} / \boldsymbol{\gamma}$-BHC}

Residues of $\mathrm{BHC}$ isomers in significant concentrations in the sediments may be attributed to the heavy use of this pesticide in Indian agriculture until recently. The ratios of $\alpha$ - to $\gamma$ - isomer in the present study ranged from 0.05 17.59 , suggesting for the earlier use of BHC with signature of continued recent use.

\subsection{Percentage distribution of Isomers}

\subsubsection{BHC Isomers}

The concentration of the four isomers of BHC reveals a heterogenic nature of distribution. The composition of $\mathrm{BHC}$ isomers may be relative to isomerization of $\mathrm{BHC}$ during the process of transport and transformation. $\alpha$-BHC may eventually be converted to $\gamma$-BHC. In premonsoon season, no definite trend was observed for the BHC isomers except for $\alpha$-BHC which showed an increasing trend from Ramghat to Kalindi Kunj which could be due to discharges from drains joining the river Yamuna. No trend was observed for BHC isomers during monsoon and post- monsoon. However, during postmonsoon, concentration of $\gamma$-BHC was higher than $\alpha$ BHC which implies that $\alpha$-BHC got transformed to $\gamma$ $\mathrm{BHC}$ in post- monsoon. Percentage distribution of BHC Isomers in Pre-monsoon, Monsoon and Post-monsoon season has been given in Figure 2.

\subsubsection{DDD and DDE}

The composition of organochlorines and its metabolites can provide a tool for better understanding of the origin and transport pathways of these contaminants in the environment. Both DDD and DDE are degradation products of DDT. While DDE is the more stable end-product, resistant to further degradation, DDD is an intermediate metabolite in conversion of DDT to DDE. In this study, the percent distribution of DDD was higher than DDE suggesting fresh input of DDT rather than historical usage.

Table 5. Isomeric Ratios of OCPs.

\begin{tabular}{|c|c|c|c|c|c|c|c|c|c|c|c|c|}
\hline \multicolumn{2}{|c|}{ Isomers } & \multicolumn{3}{|c|}{ Dield/Ald } & \multicolumn{3}{|c|}{ Нерех/Нер } & \multicolumn{3}{|c|}{ DDD/DDE } & \multicolumn{2}{|c|}{ al-BHC/g-BHC } \\
\hline Sites & PrM & Mon & PoM & PrM & Mon & PoM & PrM & Mon & PoM & PrM & Mon & PoM \\
\hline RG & 1.61 & 12.2 & 2.94 & 0.37 & 2.03 & 2.74 & 0.36 & 0.47 & 1.12 & 1.28 & 1.16 & 0.58 \\
\hline NGUS & 1.74 & 0.86 & 3.4 & 1.87 & 0.42 & 2.79 & 1.01 & 0.22 & 0.51 & 10.39 & 1.25 & 0.07 \\
\hline NGDS & 1.71 & 1.27 & 3.84 & 0.44 & 8.03 & 5.52 & 0.5 & 0.46 & 0.48 & 1.58 & 0.84 & 0.05 \\
\hline ITO & 2.41 & 3.37 & 1.55 & 5.69 & 8.28 & 1.2 & 1.07 & 0.4 & 0.66 & 1.94 & 1.64 & 0.84 \\
\hline OK & 2.05 & 1.06 & 1.4 & 10.18 & 1.41 & 1.04 & 0.95 & 0.69 & 0.58 & 17.59 & 0.92 & 0.63 \\
\hline KK & 2.15 & 1.32 & 1.66 & 10.36 & 4.58 & 8.25 & 0.5 & 0.55 & 0.46 & 6.93 & 0.72 & 0.48 \\
\hline
\end{tabular}



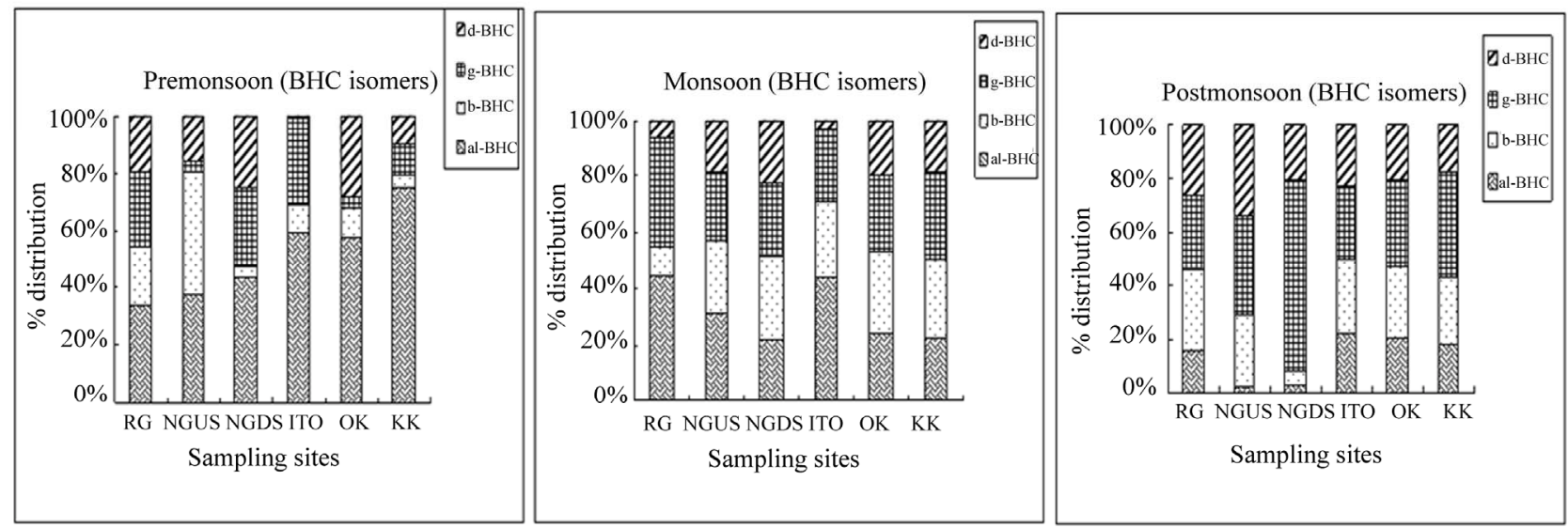

Figure 2. Percentage distribution of BHC Isomers in Pre-monsoon, Monsoon and Post-monsoon season.

This can be attributed to the fact that vector control programmes are more effective in urban areas. Percentage distribution of DDD and DDE in Pre-monsoon, Monsoon and Post-monsoon season is given in Figure 3.

\subsection{Comparison with Other Studies at National Level}

The concentrations of individual OCPs reported in this study are consistent with other studies of OCPs reported at the national level. However, the values reported in Kolleru lake wetland [20] are exceedingly high compared to this study, which has been attributed to intensive use of organochlorine pesticides in the Kolleru lake region. A comparative account of the literatures reporting study of OCPs in India has been mentioned in Table 6.

\subsection{Comparison with Other Studies at International Level}

This study is also in agreement with other studies reported at the international level, as the values of OCPs observed in this study are comparable to those reported by other authors. Table 7 lists different studies together with the individual OCP concentrations observed in dif- ferent parts of the world.

\section{Conclusions}

On the basis of the results obtained, it can be safely concluded that Endosufan sulfate + DDT, Endrin aldehyde, DDD, Endrin and Methoxychlor were found in significant concentrations at all the sites in all the seasons, indicating their wide use. No definite trend at six sampling sites was observed, however, the site RG was observed to have been the prominent recipient site in post-monsoon and site KK also observed highest OCP concentration in Monsoon. Correlation coefficient matrix for individual OCPs in sediment revealed significant correlations between various components in the sediments, with correlation coefficients frequently greater than 0.5 . The concentration of the four isomers of BHC reveals a heterogenic nature of distribution with no definite trend in any of the seasons. The ratios of Dieldrin/Aldrin, Heptachlor epoxide/Heptachlor, DDD/DDE and $\alpha$-BHC $/ \gamma$-BHC revealed a heterogenous nature, with degradation of OCPs at almost all the sites with fresh input of OCPs intermittently.

Although the values of OCPs in sediments reported in
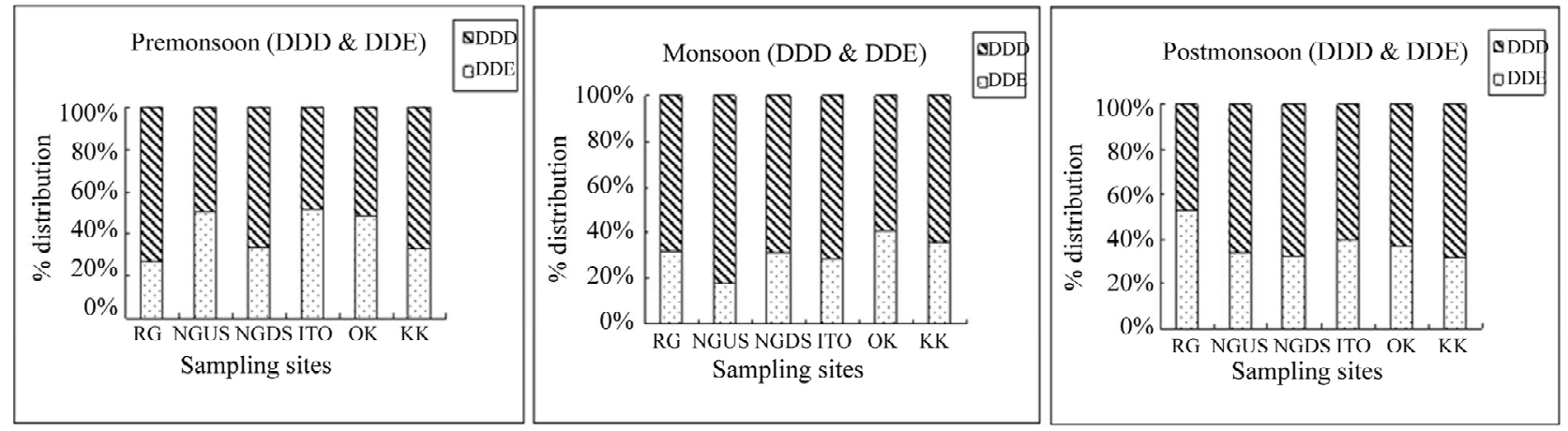

Figure 3. Percentage distribution of DDD and DDE in Pre-monsoon, Monsoon and Post-monsoon season. 
Table 6. Comparison of the present study with other studies within India.

\begin{tabular}{|c|c|c|c|c|}
\hline Location & Year & OCPs & Values(ng/g) & Reference \\
\hline \multirow[t]{17}{*}{ Yamuna river, Delhi } & Present Study & al-HCH & $0.24-25.49$ & Present Study \\
\hline & & $\mathrm{b}-\mathrm{HCH}$ & $0.31-30.27$ & \\
\hline & & $\mathrm{g}-\mathrm{HCH}$ & $0.37-27.85$ & \\
\hline & & $\mathrm{d}-\mathrm{HCH}$ & $0.11-20.99$ & \\
\hline & & Heptachlor & $0.79-25.23$ & \\
\hline & & Aldrin & $1.05-29.1$ & \\
\hline & & Heptachlor epoxide & $2.09-78.18$ & \\
\hline & & g-Chlordane & $1.32-23.71$ & \\
\hline & & Endosulfan $1+$ al-Chlordane & $0.11-23.54$ & \\
\hline & & $\mathrm{DDE}$ & $3.45-72.16$ & \\
\hline & & Endrin & $12.14-67.63$ & \\
\hline & & Endosulfan 2 & $11.34-60.51$ & \\
\hline & & DDD & $13.42-64.19$ & \\
\hline & & Endrin aldehyde & $21.89-90.87$ & \\
\hline & & Endosulfan sulfate+ DDT & $20.59-86.19$ & \\
\hline & & Endrin ketone & $5.9-58.58$ & \\
\hline & & Methoxychlor & $7.72-62.78$ & \\
\hline \multirow[t]{3}{*}{ Bay of Bengal, India } & 2005 & DDE & $0.03-4.42$ & Babu Rajendran et al., 2005 \\
\hline & & DDD & $0.01-0.53$ & \\
\hline & & DDT & $0.01-0.02$ & \\
\hline \multirow[t]{8}{*}{ Hugli estuary, India } & 2003 & al-HCH & BDL-0.003 & Bhattacharya et al., 2003 \\
\hline & & b-HCH & BDL-0.25 & \\
\hline & & g-HCH & BDL-0.16 & \\
\hline & & d-HCH & BDL-0.006 & \\
\hline & & DDT & BDL-0.11 & \\
\hline & & DDE & BDL-0.01 & \\
\hline & & Endosulfan 1 & BDL-0.008 & \\
\hline & & Endosulfan sulfate & BDL-0.4 & \\
\hline \multirow[t]{5}{*}{ West coast of India } & 1997 & $\mathrm{t}-\mathrm{HCH}$ & $0.85-7.87$ & Sarkar et al., 1997 \\
\hline & & Aldrin & $0.1-0.27$ & \\
\hline & & Dieldrin & $0.7-3.33$ & \\
\hline & & Endrin & $0.42-0.95$ & \\
\hline & & $\mathrm{t}-\mathrm{DDT}$ & $1.47-25.17$ & \\
\hline \multirow[t]{4}{*}{ East and West coast of India } & 2001 & al-HCH & BDL-721.88 & Pandit et al., 2001 \\
\hline & & b-HCH & BDL-251.7 & \\
\hline & & $\mathrm{g}-\mathrm{HCH}$ & BDL-55.6 & \\
\hline & & d-HCH & BDL-79.9 & \\
\hline
\end{tabular}




\begin{tabular}{|c|c|c|c|c|}
\hline & & DDE & BDL-464.55 & \\
\hline & & DDD & BDL-17.88 & \\
\hline & & DDT & BDL-109.5 & \\
\hline & & Aldrin & BDL-3 & \\
\hline & & Endosulfan 1 & BDL-1.4 & \\
\hline & & Endosulfan 2 & BDL-0.1 & \\
\hline \multirow[t]{10}{*}{ Hugli estuary, northeast India } & 2005 & al-HCH & $0.05-0.26$ & Guzzella et al.,2005 \\
\hline & & b-HCH & $<0.05-0.06$ & \\
\hline & & $\mathrm{g}-\mathrm{HCH}$ & $0.06-0.15$ & \\
\hline & & $\mathrm{d}-\mathrm{HCH}$ & $<0.05$ & \\
\hline & & DDE & $<0.01-0.39$ & \\
\hline & & DDD & $<0.01-0.35$ & \\
\hline & & DDT & $0.12-1.29$ & \\
\hline & & Dieldrin & $<0.05$ & \\
\hline & & Endrin & $<0.05$ & \\
\hline & & Methoxychlor & $<0.1$ & \\
\hline \multirow[t]{5}{*}{ Himalayan Lakes } & 1997 & DDE & $<0.4-10.48$ & Galassi et al.,1997 \\
\hline & & DDD & $<0.4-0.63$ & \\
\hline & & DDT & $0.44-5.84$ & \\
\hline & & $\mathrm{g}-\mathrm{HCH}$ & $1.17-2.89$ & \\
\hline & & $\mathrm{HCB}$ & ND -1.10 & \\
\hline \multirow[t]{2}{*}{ Yamuna river, Delhi, India } & 1999 & $\mathrm{t}-\mathrm{DDT}$ & $17.10-236.62$ & Sethi et al.,1999 \\
\hline & & $\mathrm{t}-\mathrm{HCH}$ & $2.635-36.265$ & \\
\hline \multirow[t]{5}{*}{ Kolleru lake wetland, India } & 2006 & al-BHC & $22.4-174.2 \mu \mathrm{g} / \mathrm{g}$ & Amaraneni, 2006 \\
\hline & & $\mathrm{g}-\mathrm{BHC}$ & $44.2-234 \mu \mathrm{g} / \mathrm{g}$ & \\
\hline & & Endosulfan & $89.6-238 \mu \mathrm{g} / \mathrm{g}$ & \\
\hline & & Dieldrin & $\mathrm{BDL}-19.6 \mu \mathrm{g} / \mathrm{g}$ & \\
\hline & & DDT & BDL - $128.6 \mu \mathrm{g} / \mathrm{g}$ & \\
\hline
\end{tabular}

Table 7. Comparison of the present study with other studies at the International level.

\begin{tabular}{|c|c|c|c|c|}
\hline Location & Year & OCPs & Values(ng/g) & Reference \\
\hline \multirow[t]{11}{*}{ Yamuna river, Delhi } & 2006 & al-HCH & $0.24-25.49$ & Present Study, 2006 \\
\hline & & $\mathrm{b}-\mathrm{HCH}$ & $0.31-30.27$ & \\
\hline & & $\mathrm{g}-\mathrm{HCH}$ & $0.37-27.85$ & \\
\hline & & $\mathrm{d}-\mathrm{HCH}$ & $0.11-20.99$ & \\
\hline & & Heptachlor & $0.79-25.23$ & \\
\hline & & Aldrin & $1.05-29.1$ & \\
\hline & & Heptachlor epoxide & $2.09-78.18$ & \\
\hline & & g-Chlordane & $1.32-23.71$ & \\
\hline & & Endosulfan $1+$ al-Chlordane & $0.11-23.54$ & \\
\hline & & $\mathrm{DDE}$ & $3.45-72.16$ & \\
\hline & & Dieldrin & $5.49-81.8$ & \\
\hline
\end{tabular}




\begin{tabular}{|c|c|c|c|c|}
\hline & & Endrin & $12.14-67.63$ & \\
\hline & & Endosulfan 2 & $11.34-60.51$ & \\
\hline & & DDD & $13.42-64.19$ & \\
\hline & & Endrin aldehyde & $21.89-90.87$ & \\
\hline & & Endosulfan sulfate + DDT & $20.59-86.19$ & \\
\hline & & Endrin ketone & $5.9-58.58$ & \\
\hline & & Methoxychlor & $7.72-62.78$ & \\
\hline \multirow[t]{19}{*}{ Coastal marine sediment, Singapore } & 2005 & al-HCH & $0.9-9.3$ & Wurl and Obbard, 2005 \\
\hline & & $\mathrm{b}-\mathrm{HCH}$ & $0.7-11.1$ & \\
\hline & & $\mathrm{g}-\mathrm{HCH}$ & $<0.7-13.4$ & \\
\hline & & $\mathrm{d}-\mathrm{HCH}$ & $0.9-13.3$ & \\
\hline & & DDT & $<0.5-4.2$ & \\
\hline & & DDD & $1.3-4.0$ & \\
\hline & & $\mathrm{DDE}$ & $0.6-4.7$ & \\
\hline & & al-Chlordane & $<0.3-9.0$ & \\
\hline & & g-Chlordane & $1.2-10$ & \\
\hline & & Heptachlor & $<0.9-9.0$ & \\
\hline & & Heptachlor epoxide & $<0.7-6.8$ & \\
\hline & & Aldrin & $<0.3-1.4$ & \\
\hline & & Dieldrin & $<1.3-3.4$ & \\
\hline & & Endrin & $<1.3-4.0$ & \\
\hline & & Endrin aldehyde & $<2.0-4.2$ & \\
\hline & & Endosulfan 1 & $<0.9-2.2$ & \\
\hline & & Endosulfan 2 & $<1.0-1.6$ & \\
\hline & & Endosulfan sulfate & $<0.7-1.3$ & \\
\hline & & Methoxychlor & $<0.4-1.2$ & \\
\hline \multirow[t]{3}{*}{ River Po sediment, } & 2002 & DDT & $0.6-3.1$ & Camusso et al.,2002 \\
\hline & & DDD & $0.4-1.8$ & \\
\hline & & DDE & $0.8-11.1$ & \\
\hline \multirow[t]{3}{*}{ Ebro river, Mediterranean Sea } & 2006 & DDT & $1.3-7.2$ & Gomez-Gutierrez et al., 2006 \\
\hline & & Lindane & $0.54-5.64$ & \\
\hline & & $\mathrm{HCB}$ & $0.43-1.21$ & \\
\hline \multirow[t]{3}{*}{ Paranoa lake, Brazil } & 1999 & $\mathrm{HCH}$ & $0.49-0.9$ & Caldas et al., 1999 \\
\hline & & Heptachlor epoxide & $0.14-2.0$ & \\
\hline & & DDE & $0.52-12.6$ & \\
\hline \multirow[t]{9}{*}{ Coastal lagoon watershed, Argentina } & 2001 & $\mathrm{HCH}$ & $57-156$ & Menone et al., 2001 \\
\hline & & Heptachlor & $<0.1-2$ & \\
\hline & & Heptachlor epoxide & $581-1302$ & \\
\hline & & Dieldrin & $3.0-14$ & \\
\hline & & Endrin & $<0.1-17$ & \\
\hline & & Endosulfan 1 & $0.2-3.0$ & \\
\hline & & Endosulfan 2 & $<0.2-11$ & \\
\hline & & Endosulfan sulfate & $4.0-58$ & \\
\hline & & Methoxychlor & $<0.2-127$ & \\
\hline
\end{tabular}




\begin{tabular}{|c|c|c|c|c|}
\hline \multirow[t]{6}{*}{ Bay of Ohuira, Mexico } & \multirow[t]{6}{*}{2002} & d-HCH & $11-119$ & \multirow[t]{6}{*}{ Osuna-Flores and Riva, 2002} \\
\hline & & DDT & BDL-26 & \\
\hline & & $\mathrm{DDE}$ & $12-123$ & \\
\hline & & Endosulfan 1 & BDL-45 & \\
\hline & & Heptachlor & BDL-57 & \\
\hline & & Heptachlor epoxide & $20-132$ & \\
\hline \multirow[t]{2}{*}{ Haleji lake, Pakistan } & \multirow[t]{2}{*}{2002} & $\mathrm{HCB}$ & $0.4-1.7$ & \multirow[t]{2}{*}{ Sanpera et al., 2002} \\
\hline & & $\mathrm{DDE}$ & $1.4-10.3$ & \\
\hline \multirow[t]{2}{*}{ Stream sediment, Spain } & \multirow[t]{2}{*}{2005} & al-HCH & $29-387$ & \multirow[t]{2}{*}{ Gonzalez-Lopez et.al.,2005 } \\
\hline & & b-HCH & $45-392$ & \\
\hline \multirow[t]{7}{*}{ Farming community, Ghana } & \multirow[t]{7}{*}{2001} & $\mathrm{HCB}$ & 0.9 & \multirow[t]{7}{*}{ Ntow, 2001} \\
\hline & & Lindane & 3.2 & \\
\hline & & DDE & 0.46 & \\
\hline & & Heptachlor epoxide & 0.63 & \\
\hline & & Endosulfan 1 & 0.19 & \\
\hline & & Endosulfan 2 & 0.13 & \\
\hline & & Endosulfan sulfate & 0.23 & \\
\hline \multirow[t]{6}{*}{ Lake Orta sediments, Italy } & \multirow[t]{6}{*}{1997} & al-HCH & $0.04-0.61$ & \multirow[t]{6}{*}{ Guzzella, 1997} \\
\hline & & b-HCH & $0.07-11.03$ & \\
\hline & & $\mathrm{g}-\mathrm{HCH}$ & $0.24-13.73$ & \\
\hline & & DDT & $0.14-9.02$ & \\
\hline & & DDD & $0.03-58.38$ & \\
\hline & & DDE & $0.0-1.47$ & \\
\hline \multirow[t]{18}{*}{ Tampa Bay, Florida } & \multirow[t]{18}{*}{2004} & al-HCH & 0.09 & \multirow[t]{18}{*}{ Grabe and Barro, 2004} \\
\hline & & b-HCH & 0.16 & \\
\hline & & $\mathrm{g}-\mathrm{HCH}$ & 0.19 & \\
\hline & & $\mathrm{d}-\mathrm{HCH}$ & 0.23 & \\
\hline & & DDT & 0.31 & \\
\hline & & DDD & 0.49 & \\
\hline & & DDE & 0.81 & \\
\hline & & Chlordane & 1.76 & \\
\hline & & Heptachlor & 0.78 & \\
\hline & & Heptachlor epoxide & 0.04 & \\
\hline & & Aldrin & 0.23 & \\
\hline & & Dieldrin & 0.33 & \\
\hline & & Endrin & 0.18 & \\
\hline & & Endrin aldehyde & 0.1 & \\
\hline & & Endosulfan 1 & 0.53 & \\
\hline & & Endosulfan 2 & 0.12 & \\
\hline & & Endosulfan sulfate & 0.18 & \\
\hline & & Methoxychlor & 0.1 & \\
\hline \multirow[t]{3}{*}{ US Arctic lakes } & \multirow[t]{3}{*}{1997} & al-HCH & 0.04 & \multirow[t]{3}{*}{ Allen-Gil et al., 1997} \\
\hline & & $\mathrm{g}-\mathrm{HCH}$ & 0.05 & \\
\hline & & $\mathrm{g}-\mathrm{Chl}$ & ND & \\
\hline
\end{tabular}




\begin{tabular}{|c|c|c|c|c|}
\hline & & Heptachlor epoxide & ND & \\
\hline & & Endosulfan 2 & ND & \\
\hline & & DDT & 0.12 & \\
\hline & & DDD & 0.06 & \\
\hline & & DDE & 0.03 & \\
\hline \multirow[t]{11}{*}{ Uluabat lake, Turkey } & 2006 & al-HCH & $311-715$ & Barlas et al., 2006 \\
\hline & & $\mathrm{b}-\mathrm{HCH}$ & ND-559 & \\
\hline & & $\mathrm{g}-\mathrm{HCH}$ & ND-405 & \\
\hline & & $\mathrm{HCB}$ & $158-556$ & \\
\hline & & Aldrin & ND-446 & \\
\hline & & Heptachlor epoxide & $108-1533$ & \\
\hline & & Endosulfan 1 & ND & \\
\hline & & DDE & ND-1179 & \\
\hline & & Endrin & ND-580 & \\
\hline & & Endosulfan 2 & ND-248.4 & \\
\hline & & DDT & ND-1553 & \\
\hline \multirow[t]{18}{*}{ Pearl river estuary } & 2001 & al-HCH & ND-1.37 & Li et al., 2001 \\
\hline & & b-HCH & ND-1.14 & \\
\hline & & $\mathrm{g}-\mathrm{HCH}$ & ND-0.72 & \\
\hline & & $\mathrm{d}-\mathrm{HCH}$ & $0.43-3.71$ & \\
\hline & & DDT & $1.27-6.65$ & \\
\hline & & DDD & ND-10.8 & \\
\hline & & DDE & ND-4.09 & \\
\hline & & Hep & $0.47-1.62$ & \\
\hline & & Heptachlor epoxide & $0.19-4.46$ & \\
\hline & & Aldrin & ND-0.92 & \\
\hline & & Dieldrin & ND-0.19 & \\
\hline & & Endrin & ND-0.61 & \\
\hline & & Endrin aldehyde & ND-0.17 & \\
\hline & & Endrin ketone & $1.65-7.86$ & \\
\hline & & Endosulfan 1 & ND-1.57 & \\
\hline & & Endosulfan 2 & ND-1.06 & \\
\hline & & Endosulfan sulfate & ND-41.8 & \\
\hline & & Methoxychlor & ND-1.49 & \\
\hline
\end{tabular}

the study are comparable to those by others in India as well as other parts of the world, they are much higher at some sites compared to the standards established for the sediments. In the present study, at all the sampling sites, the values of Endosulfan II and Methoxychlor were found to be much higher than the standard (1.4 and 1.9 $\mathrm{ng} / \mathrm{g}$ ) [21]. As per CPCB, India [22] the environmental standards for BHC and DDT are $10 \mu \mathrm{g} / \mathrm{L}$ each respectively. The use of persistent OCPs have been banned or severely restricted to use only in small number of countries with serious public health problems such as malaria and other parasitic diseases. However, they are still used in many developing countries including India in very large quantities, mainly because of their low cost and effectiveness. It is obvious, therefore, that the question is still a matter of concern for the global society and a call for worldwide attention through international bodies. Thus, in order to have a comprehensive picture of OCP distribution and their seasonal variation in Yamuna river sediments, a detailed study is required.

\section{Acknowledgements}

The authors are grateful to University Grants Commission, New Delhi, for providing the funds in the form of JRF (Junior Research Fellowship) to the corresponding author. They would also like to thank Mrs. Irani Mukherjee for her valuable inputs during experimentation. The corresponding author would also like to thank Dr. 
Jamson Masih for his contribution in statistical analysis and interpretation of the data.

\section{REFERENCES}

[1] W. J. Ntow, "Organochlorine Pesticides in Water, Sediment, Crops, and Human fluids in a Farming Community in Ghana," Archives of Environmental Contamination and Toxicology, Vol. 40, No. 4, 2001, pp. 557-563. doi:10.1007/s002440010210

[2] P. K. Sethi and A. K. Bhattacharya, "Current Trends of Some Organochlorinated Pesticides in Yamuna River Sediments around Delhi," Environmental Pollution Control Journal, Vol. 2, No. 3, 1999, pp. 40-43.

[3] S. Tanabe, H. Iwata and R. Tatsukawa, "Global Contamination by Persistent Organochlorines and Their Ecotoxicological Impact on Marine Mammals," Science of the Total Environment, Vol. 154, 1994, pp. 397-403. doi:10.1016/0048-9697(94)90086-8

[4] UNEP, "Global Report on Regionally Based Assessment of Persistent Toxic Substances," Geneva, Switzerland, UNEP Chemicals, 2003.

[5] R. J. Gibbs, "Mechanisms of Trace Metal Transport In Rivers," Science, Vol. 180, 1973, pp. 71-72. doi:10.1126/science.180.4081.71

[6] L. Hakanson, "Sediment variability," In: G. A. Burton Jr, Eds., Sediment Toxicity Assessment, Boca Raton, Lewis Publishers, FL, 1992, pp. 19-36.

[7] X. Li, Z. Shen, O. W. H. Wai and Y. Li, "Chemical Partitioning of Heavy Metal Contaminants in Sediment of the Pearl River Estuary," Chemical Speciation and Bioavailability, Vol. 12, No. 1, 2000, pp. 17-25. doi: $10.3184 / 095422900782775607$

[8] A. Sodergren, "Trends in Water Pollution, Consequences for Ecotoxicology”, In: J. T. Zelikoff, Ed., Ecotoxicology: Responses, Biomarkers and Risk Assessment, an OECD Workshop, SOS Publications, Fair Haven, 1997, pp. 1523.

[9] K. P. Singh, A. Malik and S. Sinha, "Persistent Organochlorine Pesticide Residues in Soil and Surface Water of Northern Indo-Gangetic Alluvial Plains," Environmental Monitoring and Assessment, Vol. 125, 2007, pp. 47-155. doi:10.1007/s10661-006-9247-0

[10] T. M. Travers, M. Beretta and M. C. Costa, "Ratio of DDT/DDE in the All Saints Bay, Brazil and its use in environmental management," Chemosphere, Vol. 38, No. 6, 1999, pp. 1445-1452. doi:10.1016/S0045-6535(98)00546-3

[11] D. Yuan, D. Yang, T. L. Wade and Y. Qian, "Status of Persistent Organic Pollutants in the Sediment from Several Estuaries in China," Environmental Pollution, Vol. 114, No. 1, 2001, pp. 101-111. doi:10.1016/S0269-7491(00)00200-1

[12] K. N. Mehrotra, "Status of Insecticide Resistance in Insect Pests," In: B. Dhaliwal and B. Singh, Eds., Pesticides -Their Ecological Impact in Developing Countries, New Delhi7 Commonwealth Publishers, 1993, p. 30.
[13] J. E. Cavanagh, K. A. Burns, G. J. Brunskill and R. J. Coventry, "Organochlorine Pesticide Residues in Soils and Sediments of the Herbert and Burdekin River Regions, North Queensland-Implications for Contamination of the Great Barrier Reef," Marine Pollution Bulletin, Vol. 39, No. 112, 1999, pp. 367-375. doi:10.1016/S0025-326X(99)00058-2

[14] R. D. Wauchope, T. M. Buttler, A. G. Hornsby, P. W. M. Augustijn Beckers and J. P. Burt, "SCS/ARS/CES Pesticide Properties Database for Environmental Decision Making," Reviews of Environmental Contamination and Toxicology, Vol. 123, 1992, pp. 1-157.

[15] H. Kidd and D. R. James, (Eds.), "The Agrochemicals Handbook," Third Edition, Royal Society of Chemistry Information Services, Cambridge, UK, 1991.

[16] ATSDR: U.S. Department of Health and Human Services, Public Health Service Agency for Toxic Substances and Disease Registry, September 2002.

[17] L. H. Keith, "Environmental Endocrine Disrupters: A Handbook of Property Data," Wiley, New York, 1997, p. 621.

[18] C. Sanpera, X. Ruiz, G. A. Llorente, L. Jover and R. Jabeen, "Persistent Organochlorine Compounds in Sediment and Biota from the Haleji Lake: A Wildlife Sanctuary in South Pakistan," Bulletin of Environmental Contamination and Toxicology, Vol. 68, 2002, pp. 237-244. doi: $10.1007 / \mathrm{s} 001280244$

[19] X. D. Li, B. X. Mai, G. Zhang, G. Y. Sheng, J. M. Fu, S. M. Pan, O. W. H. Wai and Y. S. Li, "Distribution of Organochlorine Pesticides in a Sediment Profile of the Pearl River Estuary," Bulletin of Environmental Contamination and Toxicology, Vol. 67, 2001, pp. 871-880. doi: $10.1007 / \mathrm{s} 001280203$

[20] A. S. Rao, "Distribution of pesticides, PAHs and Heavy Metals in Prawn Ponds near Kolleru Lake Wetland, India," Environment International, Vol. 32, No. 3, 2006, pp. 294-302. doi:10.1016/j.envint.2005.06.001

[21] CCME, 2002, Canadian Council of Ministers of the Environment, 2002, Canadian Environmental Quality Guidelines, Winnipeg Canada.

[22] http://www.cpcb.nic.in/standard

[23] R. Babu Rajendran, T. Imagawaa, H. Tao and R. Ramesh, "Distribution of PCBs, HCHs and DDTs, and their ecotoxicological implications in Bay of Bengal, India," Environment International, Vol. 31, No. 4, 2005, pp. 503512. doi:10.1016/j.envint.2004.10.009

[24] B. Bhattacharya, S. K. Sarkar and N. Mukherjee, "Organochlorine Pesticide Residues in Sediments of a Tropical Mangrove Estuary, India: Implications for Monitoring," Environment International, Vol. 29, 2003, pp. 587592. doi:10.1016/S0160-4120(03)00016-3

[25] A. Sarkar, R. Nagarajan, S. P. Chaphadkar and S. Y. S. Singbal, "Contamination of Organochlorine Pesticides in Sediments from the Arabian Sea along the West Coast of India," Water Research, Vol. 31, No. 2, 1997, pp. 195200. doi:10.1016/S0043-1354(96)00210-2 
[26] G. G. Pandit, A. M. Mohan Rao, S. K. Jha, T. M. Krishnamoorthy, S. P. Kale, K. Raghu and N. B. K. Murthy, "Monitoring of Organochlorine Pesticide Residues in the Indian Marine Environment," Chemosphere, Vol. 44, No. 2, 2001, pp. 301-305. doi:10.1016/S0045-6535(00)00179-X

[27] L. Guzzella, C. Roscioli, L. Vigano, M. Saha, S. K. Sarkar and A. Bhattacharya, "Evaluation of the Concentration of HCH, DDT, HCB, PCB and PAH in the Sediments along the Lower Stretch of Hugli Estuary, West Bengal, Northeast India," Environment International, Vol. 31, No. 4, 2005, pp. 523-534. doi:10.1016/i.envint.2004.10.014

[28] S. Galassi, S. Valsecchi and G. A. Tartari, "The distribution of PCB's and Chlorinated Pesticides in two Connected Himalayan Lakes," Water, Air and Soil Pollution, Vol. 99, No. 1-4, 1997, pp. 717-725. doi:10.1007/BF02406911

[29] O. Wurl and J. P. Obbard, "Organochlorine Pesticides, Polychlorinated Biphenyls and Polybrominated Diphenyl Ethers in Singapore's Coastal Marine Sediments," Chemosphere, Vol. 58, No. 11, 2005, pp. 925-933. doi:10.1016/j.chemosphere.2004.09.054

[30] M. Camusso, S. Galassi and D. Vignati, "Assessment of River Po Sediment Quality by Micropollutant Analysis," Water Research, Vol. 36, No. 10, 2002, pp. 2491-2504. doi:10.1016/S0043-1354(01)00485-7

[31] A. I. Gomez-Gutierrez, E. Jover, L. Bodineau, J. Albaiges and J. M. Bayona, "Organic Contaminant Loads into the Western Mediterranean Sea: Estimate of Ebro River inputs," Chemosphere, Vol. 65, No. 2, 2006, pp. 224-236. doi:10.1016/j.chemosphere.2006.02.058

[32] E. D. Caldas, R. Coelho, L. C. K. R. Souza and S. C. Siba, "Organochlorine Pesticides in Water, Sediment, and Fish of Paranoa Lake of Brasilia, Brazil," Bulletin of Environmental Contamination and Toxicology, Vol. 62, No.
2, 1999, pp. 199-206. doi: $10.1007 / \mathrm{s} 001289900860$

[33] M. L. Menone, J. E. Aizpun de Moreno, V. J. Moreno, A. L. Lanfranchi, T. L. Metcalfe and C. D. Metcalfe, "Organochlorine Pesticides and PCBs in a Southern Atlantic Coastal Lagoon Watershed, Argentina," Archives of Environmental Contamination and Toxicology, Vol. 40, 2001, pp. 355-362. doi:10.1007/s002440010183

[34] I. Osuna-Flores and M. C. Riva, Environmental Contamination and Toxicology, Vol. 68, 2002, pp. 532-539.

[35] N. Gonzalez-Lopez, R. Rial-Otero, B. Cancho-Grande, J. Simal-Gandara and B. Soto-Gonzalez, "Occurrence of Organochlorine Pesticides in Stream Sediments from an Industrial Area," Archives of Environmental Contamination and Toxicology, Vol. 48, No. 3, 2005, pp. 296-302. doi:10.1007/s00244-004-0070-8

[36] A. Grabe Stephen, Joseph Barron, "Sediment Contamination, By Habitat, In the Tampa Bay Estuarine System (1993-1999): PAHs, Pesticides and PCBs," Environmental Monitoring and Assessment, Vol. 91, No. 1-3, 2004, pp. 105-144.

[37] S. M. Allen-Gil, C. P. Gubala, D. H. Landers, B. K. Lasorsa, , E. A. Crecelius and L. R. Curtis, "Heavy Metal Accumulation in Sediment and Freshwater Fish in U.S. Arctic Lakes," Environmental Toxicology and Chemistry, Vol. 16, 1997, pp. 733-741. doi:10.1002/etc.5620160418

[38] N. Barlas, I. Very and N. Akbulut, "The Contamination Levels of Organochlorine Pesticides in Water and Sediment Samples in Lake Uluabat, Turkey," Environmental Monitoring and Assessment, Vol. 118, 2006, pp. 383-391. doi:10.1007/s10661-006-1504-8

[39] L. Guzzella, "PCBs and Organochlorine Pesticides in Lake Orta (Northern Italy) Sediments," Water, Air and Soil Pollution, Vol. 99, No. 1-4, 1997, pp. 245-254. doi:10.1007/BF02406864 